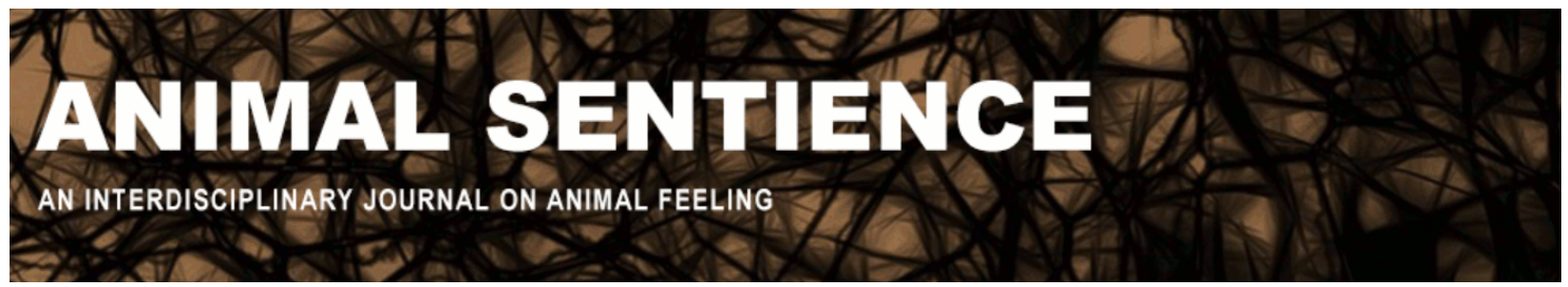

Dulany, Donelson E. (2020) Human-controlled survival of nonhumans. Animal Sentience 27(14)

DOI: $10.51291 / 2377-7478.1546$

Date of submission: 2020-01-14

Date of acceptance: 2020-01-22

(c) (†)

This article has appeared in the journal Animal

Sentience, a peer-reviewed journal on animal

cognition and feeling. It has been made open access,

free for all, by WellBeing International and deposited

in the WBI Studies Repository. For more information,

please contact

wbisr-info@wellbeingintl.org.

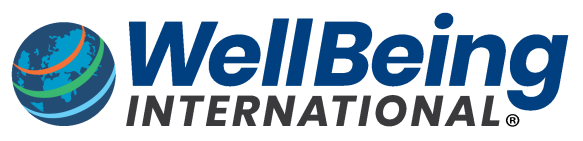

SOLUTIONS FOR PEOPLE, ANIMALS AND ENVIRONMENT 


\title{
Human-controlled survival of nonhumans
}

Commentary on Treves et al. on Just Preservation

\author{
Donelson E. Dulany \\ Department of Psychology, University of Illinois
}

\begin{abstract}
Treves et al. are right about the need for morally just preservation of nonhumans. Their suggestions can move us in that direction. But isn't what only humans are capable of doing in analyzing and solving these problems, in its broadest sense, "anthropocentrism"?
\end{abstract}

Donelson E. Dulany is Professor Emeritus of Psychology. The focus of his work has been the development of metatheory of the role of conscious contents and nonconscious operations in explicit and implicit processing with theoretical and experimental analyses of volitional control, learning, and causal reasoning. Website

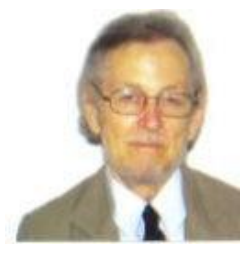

Treves, Santiago-Avila, and Lynn (2019) are right that we need "world views that incorporate multi-species justice" for "just preservation" of nonhuman species. But it seems rather obvious that it is the thoughts, values, decisions, and numerous complex actions of humans that are needed to engineer just preservation. (To use the term a little broadly: all of that is unavoidably "anthropocentric.") What are the international, cultural, and economic dangers for nonhuman and human survival? What might humans do to support the survival of humans and nonhumans? We are faced with political as well as scientific challenges.

Treves et al. recognize that global warming is extremely serious and an alarming danger for both humans and nonhumans. It was humans, not nonhumans, who laid out the Paris Accords (though these have apparently proved too profit-threatening for some, including the one national leader who withdrew). We can also recognize that a young girl has brought out supportive crowds intercontinentally. Some humans might move us toward a possible solution: oil fields and coal mines replaced by windmills and water mills in rivers, streams, and ocean tides; and more solar panels - though solving the grand problem will no doubt create still further problems, such as human employment.

For the salvation of nonhuman animals, I see promise in the scientific study of animal sentience of a particular kind: felt states of consciousness activated by symbolic representations. We humans can symbolically represent an event or person in conscious perception, activating a feeling; it is reasonable to assume a similar process in nonhuman species. Conscious states are the sole carriers of symbolic representations (Dulany, 2009, 2014). They are essential for generating the feelings of desire that lead to mating and the feelings of fear that lead to avoidance (a view similar to that of Reber 2016 in this journal and 2019). Brain imaging, a developing technology with values and limitations (Dulany, 2014; Poldrack, 2018), can help identify the general conscious state, if not its specific content. 


\section{References}

Dulany, D. (2009). Psychology and the study of consciousness. In Baynes, T., Cleeremans, A., \& Wilken, P. (Eds.), The Oxford Companion to Consciousness. Oxford University Press, Oxford, UK. pp. 540-544.

Dulany, D., (2014). What explains consciousness? Or ... what consciousness explains? Mens Sana Monographs, 12, 11-34.

Poldrack, R. (2018). The New Mind Readers: What Neuroimaging Can and Cannot Reveal About Our Thoughts. New York: Oxford University Press.

Reber, A. S. (2016). Caterpillars, consciousness and the origins of mind. Animal Sentience 11(1).

Reber, A. S. (2019). The First Minds: Caterpillars, Karyotes, and Consciousness. New York: Oxford University Press.

Treves, A., Santiago-Avila, F. J., \& Lynn, W. S. (2019). Just preservation. Animal Sentience 27(1). 


\section{PhD Scholarship in Foundations of Animal Sentience (ASENT)}

\section{London School of Economics}

The Foundations of Animal Sentience project (ASENT), a five-year ERC-funded project led by Dr. Jonathan Birch, aims to study the methodological foundations of animal sentience research and the link between sentience and animal welfare. The project seeks to recruit one PhD student. The student will contribute to the project either by exploring the methodological foundations of animal sentience research, or by investigating the pathway from animal sentience research to consequences for animal welfare legislation and policy and/or animal ethics.

The student, at the time of starting the $\mathrm{PhD}$, should have an excellent undergraduate degree and a completed Masters degree in philosophy or another relevant subject, such as comparative psychology, cognitive science, or animal welfare science. The primary supervisor of the $\mathrm{PhD}$ project will be $\mathrm{Dr}$. Jonathan Birch. If you have any questions or want to know more about the project, please write to Jonathan at j.birch2@Ise.ac.uk.

The successful applicant will receive full funding for a 4-year PhD at the LSE, including full payment of tuition fees AND a maintenance stipend of $\mathbf{\$ 1 8 , 0 0 0}$ per annum. To apply, please apply to the MPhil/PhD in Philosophy at the LSE in the usual way, carefully following all the requirements described on the LSE's website: http://www.lse.ac.uk/study-at-lse/Graduate/Degree-programmes-2020/MPhilPhDPhilosophy. When you apply, please indicate clearly in your application (in both your Statement of Academic Purpose AND your Research Proposal) that you wish to be considered for the ASENT scholarship.

You should include, in your research proposal, a substantial description (of at least 1,500 words) of a research project relevant to ASENT. You MAY, if you wish, include TWO research proposals in the same document: a proposal relevant to ASENT, and a proposal on a different subject that you would pursue if awarded an LSE Studentship or a LAHP (AHRC) scholarship. If you do this, please indicate clearly which of the two proposals is relevant to ASENT.

\section{CLOSING DATE: 24 JANUARY 2020.}

It is expected that interviews will be conducted in late January or in February.

$\underline{\text { www.lse.ac.uk/philosophy/asent-scholarship/ }}$ 